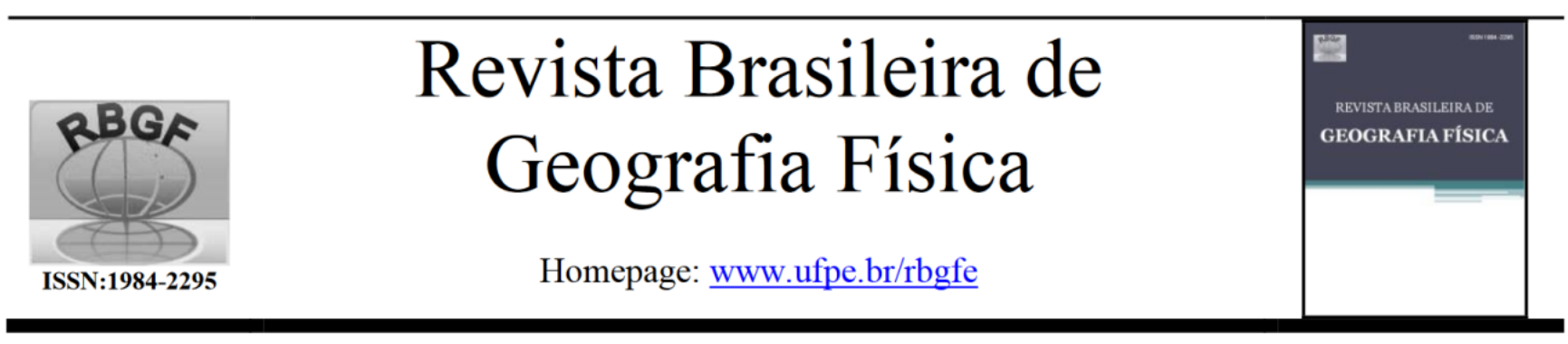

\title{
Seasonal Climate Forecast For The Alcântara Launch Center - Brazil
}

\author{
Cleber Souza Corrêa ${ }^{1}$, Michelle Simões Reboita ${ }^{2}$, Gerson Luiz Camillo ${ }^{3}$, Fabrício Pereira Härter ${ }^{4}$, Vinicius \\ Milanez Couto ${ }^{5}$ e Antonio Luis Cardoso Neto ${ }^{6}$
}

1, 3, 5, 6 Instituto de Aeronáutica e Espaço, São José dos Campos, SP, Brazil. Autor correspondente E-mail: clebercsc@fab.mil.br ${ }^{2}$ Instituto de Recursos Naturais, Universidade Federal de Itajubá (UNIFEI), Itajubá, Brazil ${ }^{4}$ Universidade Federal de Pelotas, Faculdade de Meteorologia, Pelotas, RS, Brazil

Artigo recebido em 29/04/2018 e aceito em 14/12/2018

R E S U M O

Este trabalho analisou o desempenho de três esquemas de parametrização de convecção cumulus (Kain-Fritsch, Emanuel e Grell/Emanuel) na previsão do clima sazonal, durante a transição do período chuvoso para seco (junho a julho de 2017), no Centro de Lançamento de Alcântara (CLA) - Maranhão - Brasil. Para tanto, os resultados do sistema global de previsão climática do National Centers for Environmental Prediction (NCEP-CFSv2) foram usados como condições inicial e de fronteira no Regional Climate Model (RegCM4.4). Os resultados enfocam principalmente a intensidade do vento na baixa atmosfera no CLA. As previsões desta variável foram validadas através de comparações com a reanálise ERA-Interim e com dados registrados por uma torre micrometeorológica localizada no CLA. De forma geral, as simulações com o esquema de Kain-Fritsch e Grell/Emanuel tiveram boa performance na região de estudo.

Palavras-chave: modelo climático regional (RegCM4.4), inicialização global, condições iniciais do CFSv2

\begin{abstract}
A B S T R A C T
This work analyzed the performance of three cumulus convection parameterization schemes (Kain-Fritsch, Emanuel and Grell/Emanuel) in forecasting the seasonal climate during the transition from rainy to dry period (June to July 2017) in Alcântara Launch Center (ALC) located in Maranhão State-Brazil. For this reason, the outputs from the global NCEP Climate Forecast System (CFSv2) were used as initial and boundary conditions in the Regional Climate Model (RegCM4.4). The results focused on the wind intensity in the lower atmosphere in the ALC. The forecasts of this variable were validated with comparisons with ERA-Interim reanalysis and measured data by a micrometeorological tower in ALC. In general, the simulations with Kain-Fritsch and Grell-Emanuel convective schemes had good performance in the studied region.

Keywords :regional climate model (RegCM4.4), global initialization, CFSv2 initial conditions
\end{abstract}

\section{Introduction}

The technological advances of the last decades allowed a great improvement of numerical models for weather and climate prediction. Regarding sub-seasonal and seasonal climate forecast, it can be done with regional climate models using the downscaling technique. In this technique, the outputs of global climate models are provided as initial and boundary conditions to the regional climate models. The outputs from global National Centers for Environmental Prediction (NCEP) Climate Forecast System (CFSv2) have been used as initialization for seasonal forecast studies using the Weather Research and Forecasting (WRF) model and other regional climate models. Several works have used the downscaling technique for seasonal forecasting: Siedlecki, et al. (2016), McCreight et al. (2016); Gao, et al. (2016); Zou et al. (2016); Chotamonsak et al. (2017); Ardilouze et al (2017); Weber and Mass (2017); Batté, et al. (2018) and Reboita, et al. (2018).

One regional climate model applied in studies in several regions of the globe is the Regional Climate Model (currently in the version 4) from the Earth System Physics (ESP) section from The International Center for Theoretical Physics - ICTP (Giorgi et al., 2015). RegCM4 can be initialized by different global datasets, for example, reanalyses and model outputs (like the 
climate projections from the Intergovernmental Panel on Climate Change - IPCC or climate forecasting from CFSv2).

Gonçalves (2015) carried out a study about the seasonal precipitation forecasts, in the Rio Grande do Sul state, using the CFSv2 outputs as initial and boundary conditions for RegCM4.4. Nine simulations using different cumulus parameterization schemes were performed. RegCM4.4 compared with the observations has higher correlations and smaller errors than the CFSv2. Better forecasts were obtained in the northern and western of the Rio Grande do Sul state with Grell convection scheme (with both closures, Fritsch-Chappell and Arakawa-Schubert) and with the combination of Emanuel convection scheme over the ocean and Grell over the land. Although some regions were not adequately represented by the RegCM4.4, it still had good performance in reducing the precipitation overestimations produced by CFSv2.

Reboita et al. (2018) carried out seasonal climate forecasts over Brazil with RegCM4.4 nested in two global climate models: CFSv2 and the model from the Centro de Previsão de Tempo e Estudos Climáticos (CPTEC). Precipitation simulated with Kain-Fritsch and Emanuel cumulus convection schemes, compared to the Climate Prediction Center (CPC) and the Tropical Rainfall Measuring Mission (TRMM) precipitation products, showed a better result.

In the northeast region of Brazil is located the Alcântara Launch Center (ALC). The ALC is the place where the Aeronautics Command carries out the program of launching rockets with different launching platforms, such as sounding and launching rockets for low-orbit satellites and micro-satellites (de Jesus Reuter et al., 2015). For this region, Corrêa et al. (2017) carried out climate simulations considering different scenarios (RCP4.5 and RCP 8.5) from IPCC-AR5 through dynamical downscaling of RegCM4.4 nested in the HadGEM2-ES. It was obtained a statistical parameter of the vertical profile of the wind at low atmosphere levels in order to support missions of rocket launches. Moreover, it was found oscillations in the near-surface wind intensity with a cycle of 3 to 5 days.
The purpose of this study is to analyze the performance of Kain-Fritsch, Emanuel and Grell/Emanuel cumulus convection schemes in forecasting the seasonal climate during the transition from rainy to dry period (June to July 2017) in ALC with RegCM4.4. This study can help to improve an operational seasonal forecast product of the Instituto de Aeronáutica e Espaço (available only internally), and to support operational planning in launching aerospace vehicles in the ALC.

\section{Methodology}

Three simulations (hereafter called Test 1 , Test 2 and Test 3), using RegCM4.4, were carried out from May 06, 2017 to July 30, 2017. They used, respectively, Kain-Fritsch, Emanuel and a combination of Grell (over the land)/Emanuel (over the ocean). The simulated period includes the transition from rainy to dry season in the region of ALC. May is a month of the rainy season and July is one of the dry season.

The first month of the simulations (May 2017) was excluded from the analysis as a spin-up period and only the forecasts from June and July 2017 were validated. The main focus of this study is to analyze the behavior of the near-surface wind and the sensitivity of the RegCM4.4 to different convection parameterization schemes. This work adopted the CFSv2 (Saha et al., 2014) as the initial and boundary condition for RegCM4.4.

The domain of the simulations was configured with $100 \times 120$ points (Figure 1), with $25 \mathrm{~km}$ of horizontal resolution and 23 sigmapressure vertical levels. In RegCM4.4, the surface processes can be solved through two schemes: the Biosphere-Atmosphere Transfer Scheme (BATS), or the Community Land Model (CLM) version 4.5 developed by the National Center of Atmospheric Research - NCAR (Oleson et al., 2013; Swenson and Lawrence, 2014; Pushp Raj Tiwari et al., 2015; Brunke et al., 2016 and Chen and Dirmeyer, 2017). CLM-4.5 was used in this work. Table 1 shows a summary of the physical parameterization schemes defined in the simulations. 
Table 1 Physical parameterization schemes used in the simulations.

\begin{tabular}{ll}
\hline \multicolumn{1}{c}{ Parameter } & \multicolumn{1}{c}{ Value } \\
\hline Lateral boundary conditions scheme & Relaxation, exponential technique \\
\hline Planetary Boundary Layer (PBL) scheme & Holtslag PBL, \\
\hline Cumulus Convection schemes & \\
\hline Test $\mathbf{1}$ & Kain-Fritsch (1990), Kain (2004) \\
Over land & Kain-Fritsch (1990), Kain (2004) \\
\hline Over ocean & Emanuel (1991) \\
Test 2 & Emanuel (1991) \\
Over land & \\
Over ocean & Grell (1993) \\
Test 3 & Ever land \\
Over ocean & Explicitmoisture (SUBEX) \\
\hline Moisture scheme & Zeng \\
\hline Ocean Flux scheme & 1-> (0.0065*ustar*ustar)/egrav \\
\hline Zeng Ocean model roughness formula to used & Gregorian \\
\hline Calendar & CFS01 \\
\hline Globdatparam ssttyp & CFS01 \\
\hline Globdatparam dattyp &
\end{tabular}
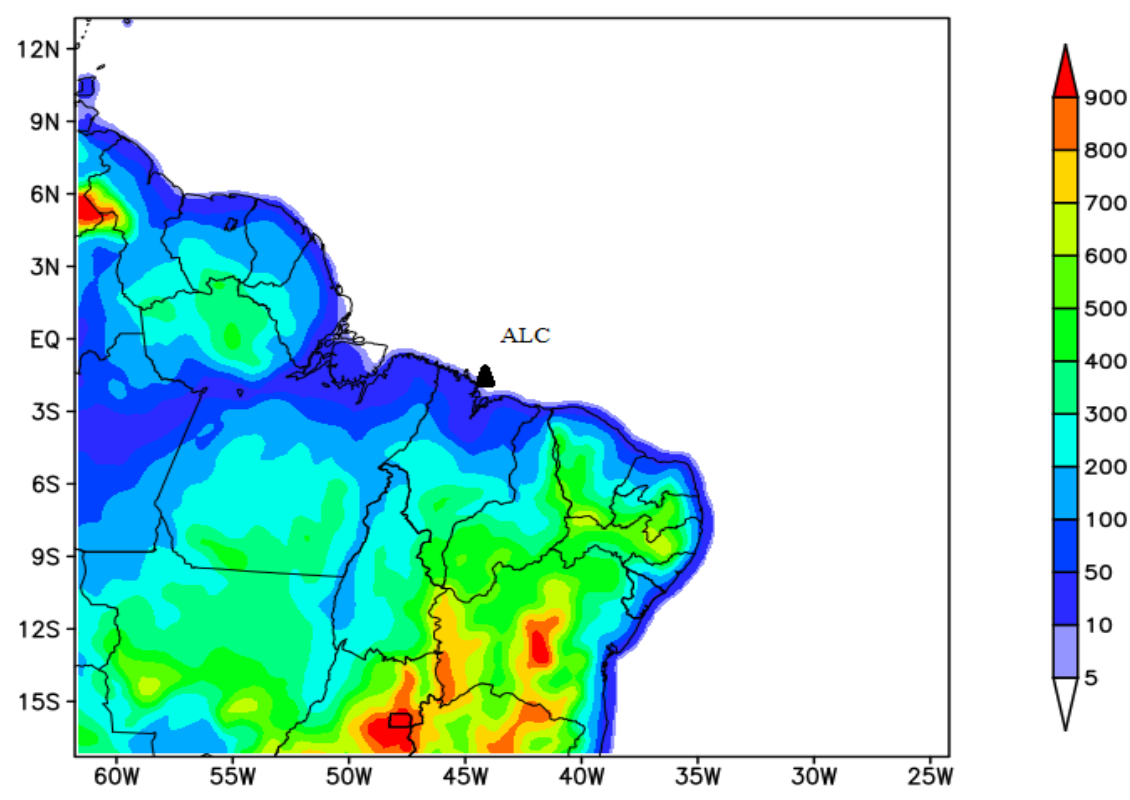

Figure 1 Topography (meters) and domain used in the simulations with RegCM4.4. The geographical location of the ALC is identified with a black dot.

\section{Validation of the Simulations}

The simulated (forecasted) air temperature at 2 meters high and the wind intensity and direction at 10 meters high were compared with ERA-Interim reanalysis (Dee et al., 2011). These data have horizontal resolution of $0.75^{\circ} \times 0.75^{\circ}$. The precipitation was validated through comparison with the Climate Prediction Center (CPC) analysis, which has $0.5^{\circ} \times 0.5^{\circ}$ of horizontal resolution. The measured direction and intensity of the wind at a micrometeorological tower $(70 \mathrm{~m})$ in ALC were used to validate the lowest level of the RegCM4.4 which is $1000 \mathrm{hPa}$. The height in meters of this level can vary according to latitude and air temperature. However, it can be accepted as approximately 110 meters. In this way, we do not expect a great agreement between the values measured in the tower and simulated by the model, 
but we expect a similarity in the variability of the time series. The wind results are also presented in wind rose graphs.

A statistical analysis is performed to estimate the wind bias and the Root Mean Squared Error (RMSE) for the months of June to July using the simulations and observational data from the micrometeorological tower. Bias is the difference between the model and the observation and RMSE is an estimate of the magnitude of bias between the model and the observed data for the period analyzed. Equation 1 is used:

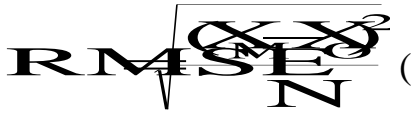

where: $X_{M}$ is the result of RegCM4.4 at level $z=$ $1000 \mathrm{hPa}$ with average wind for model integration; $X_{O}$ is the average of the observed data; $N$ is the maximum number of observations used time series. A non-parametric statistical test was used to evaluate the correlation of the observed and simulated intensity wind. The RegCM model outputs were configured to be generated every 3 hours, with eight-day values and a total of 241 values in one simulation month. Non-parametric tests have no restrictions in the sample inference process. The test used here employs a statistical permutation (Collingridge, 2013; Konietschke and Pauly, 2014; Koopman et al., 2015; Zhang et al., 2017; Pauly et al., 2018; Derrick et al. 2018). As a definition, the vector $\mathrm{P}$ with the simulated wind intensity and $\mathrm{J}(\mathrm{Nx} 1)$ with the observed wind intensity value, intend to make random permutations of $\mathrm{J}$, keeping $\mathrm{P}$ fixed. For each permutation, it calculated the correlation between vector $\mathrm{P}$ and $\mathrm{J}$, resampling the series in the order of 10,000 times, thus building the distribution of correlations (r). From these distributions, it can be obtained the value that represents the confidence interval at the level of $5 \%$ of the correlations in the upper or lower tail of distributions ( $r$ critical). The analyzed time series have 241 values. It used a subroutine program in Matlab@). The permutation test method is more robust statistically to test the correlation signal between different series that have low correlation values.

\section{Results}

Figure 2 shows the validation of air temperature at $2 \mathrm{~m}$, precipitation and intensity and direction of the wind at $10 \mathrm{~m}$ high for the average of June and July 2017. The RegCM4.4, using 3 different cumulus convection parameterization schemes, underestimates the air temperature over the continent and shows similar values over the ocean regarding the ERA-Interim reanalysis (Fig. 2a-c). Near ALC, the lowest bias in the air temperature occurs using Kain Fritsch scheme followed by Emanuel. On the other hand, the lowest bias in the precipitation in the ALC is obtained with Grell/Emanuel (Fig. 2e). For the winds at $10 \mathrm{~m}$, the three simulations show similar values near ALC, with an overestimation along the coast.

Table 2 shows some statistics calculated to wind intensity observed at $70 \mathrm{~m}$ and simulated at $1000 \mathrm{hPa}$. The 3 experiments overestimate the average of wind intensity, in about 1-2 $\mathrm{m} \mathrm{s}^{-1}$, but it was expected once the simulated winds are in a higher altitude than those of the tower.

For wind intensity, we also evaluated the correlation distributions obtained from the correlation permutation test of the original series (have a frequency of every three hours). The test is shown in Figure 3 while the original series in Figure 4. This statistic shows for Emanuel convection scheme value of 0.1564 , Grell-Emanuel convection scheme with 0.1661 and the KainFritsch convection scheme with 0.1752 (the critical values at the significance level of $5 \%$ were of the order of 0.10). These values may indicate statistic evidence that the series simulated have a significant correlation with the observed ones. All positive correlations observed are in the upper tail of the permuted correlation distribution, which can be observed in Figure 3 at the level of $5 \%$.

In June 2017, still in the transition from the rainy season, the lowest value of RMSE (3.14) was obtained with the Grell/Emanuel convection scheme (Table 2). This scheme is slightly better in the total of the analyzed period than the other schemes. Higher values of RMSE occurred in July 2017. Comparing these results, we observed that there is a small difference between the methods used a very low order magnitude between the RMSE of Kain-Fritsch and Grell/Emanuel convection schemes; therefore, there is no statistical evidence of a difference between the two parametrizations. In both situations, the Emanuel convection scheme presented lower performance compared with the others. 

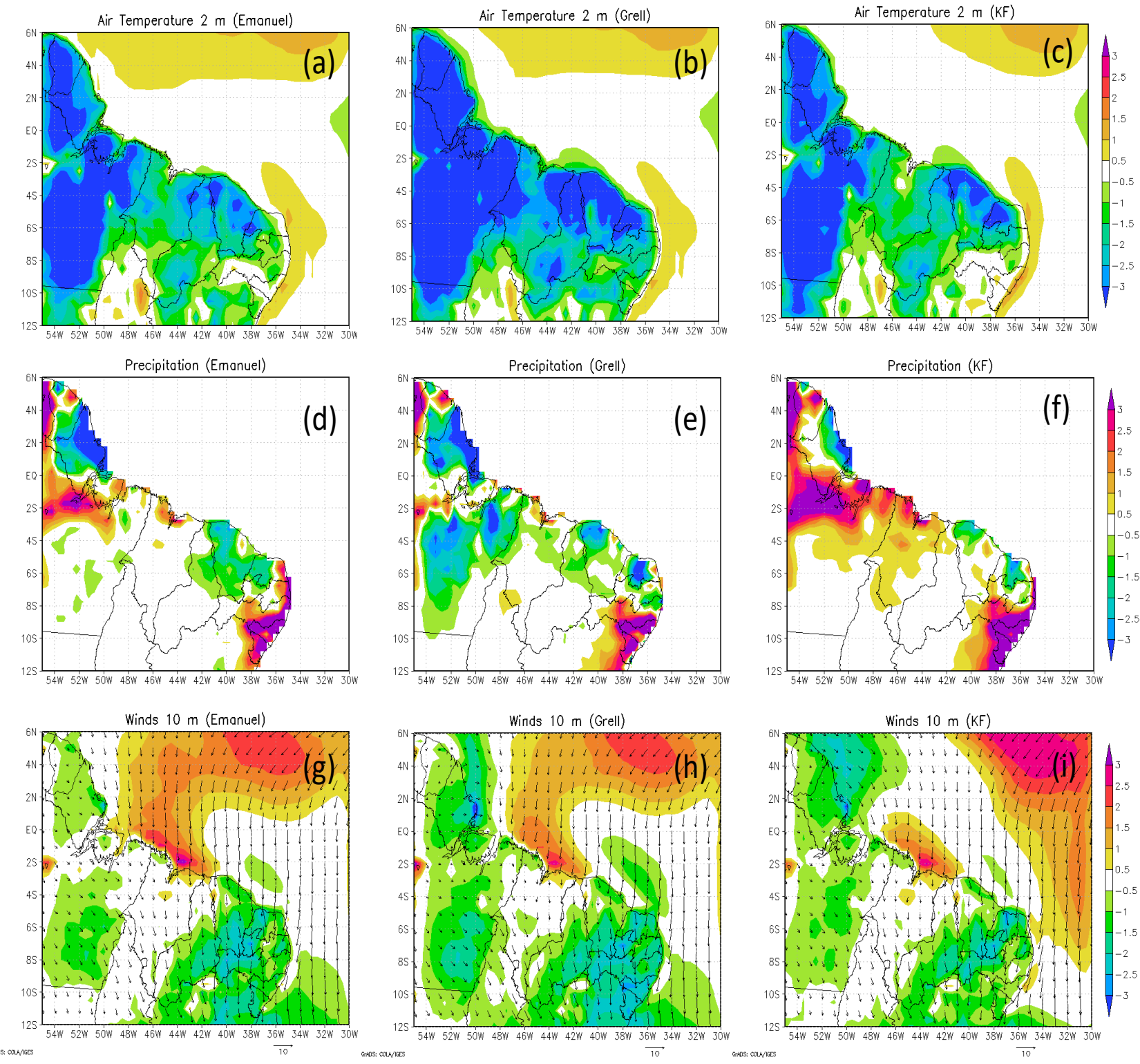

Figure 2 Difference between the RegCM4.4 monthly mean (June-July 2017) in relation to ERA-Interim for (ac) air temperature at $2 \mathrm{~m},{ }^{\circ} \mathrm{C}$, and (g-i) intensity and direction of the wind at $10 \mathrm{~m}, \mathrm{~m} \mathrm{~s}^{-1}$. For precipitation (df), the difference was computed regarding CPC, $\mathrm{mm} \mathrm{day}^{-1}$. From left to right is the simulation with Emanuel, Grell/Emanuel and Kain Fritsch convective scheme, respectively.

Table 2 Wind intensity statistical information obtained from the micrometeorological tower (70 meters) and simulated by RegCM4.4 at $1000 \mathrm{hPa}$ for June to July 2017.

\begin{tabular}{|rrrr|r|}
\hline & & Wind Intensity & \\
\hline $\begin{array}{r}\text { micrometeorological } \\
\text { tower } \mathbf{7 0 ~} \mathbf{~ m})\end{array}$ & Mean & 5.7 & 4.2 & July \\
& $\begin{array}{r}\text { Standard } \\
\text { deviation }\end{array}$ & 2.0 & 2.2 & 2.2 \\
\hline Median & 6.0 & 4.2 & 5.0 \\
\hline $\begin{array}{r}\text { Kain-Fritsch } \\
\text { Convection Scheme }\end{array}$ & Mean & 5.9 & 6.5 & 6.0 \\
& $\begin{array}{r}\text { Standard } \\
\text { deviation }\end{array}$ & 2.6 & 3.4 & 3.0
\end{tabular}


Revista Brasileira de Geografia Física v.11, n.06 (2018) 2118-2129

\begin{tabular}{|rrrr|r|}
\hline & Median & 5.8 & 6.4 & 6.0 \\
\hline $\begin{array}{r}\text { Emanuel } \\
\text { Convection Scheme }\end{array}$ & Mean & 6.5 & 6.5 & 6.5 \\
& $\begin{array}{r}\text { Standard } \\
\text { deviation }\end{array}$ & 2.6 & 3.4 & 3.0 \\
\hline $\begin{array}{r}\text { Median } \\
\text { Grell/Emanuel }\end{array}$ & Mean & 6.5 & 6.4 & 6.4 \\
\hline RMSE & $\begin{array}{r}\text { Standard } \\
\text { deviation }\end{array}$ & 2.3 & 6.7 & 6.5 \\
& $\begin{array}{r}\text { Median } \\
\text { Scheme }\end{array}$ & 6.3 & 3.3 & 2.8 \\
\hline $\begin{array}{r}\text { Convection } \\
\text { scheme } \\
\text { Kain-Fritsch } \\
\text { Convection } \\
\text { Scheme }\end{array}$ & 3.31 & 6.7 & 3.80 \\
& $\begin{array}{r}\text { Emanuel } \\
\text { Grell/Emanuel } \\
\text { Convection } \\
\text { Scheme }\end{array}$ & 3.14 & 4.12 & 3.74 \\
\hline
\end{tabular}

(a)

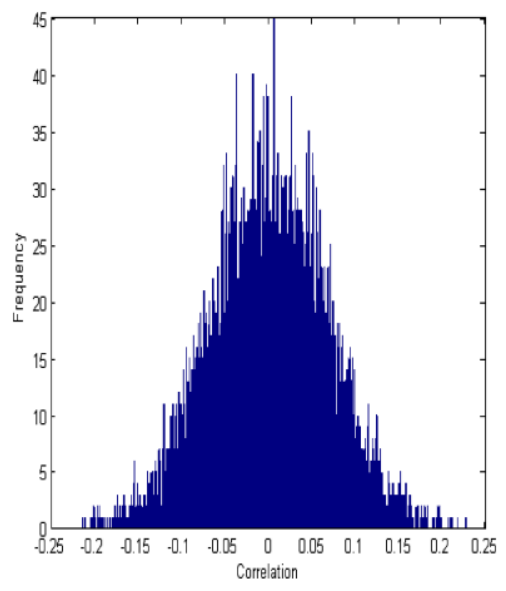

(b)

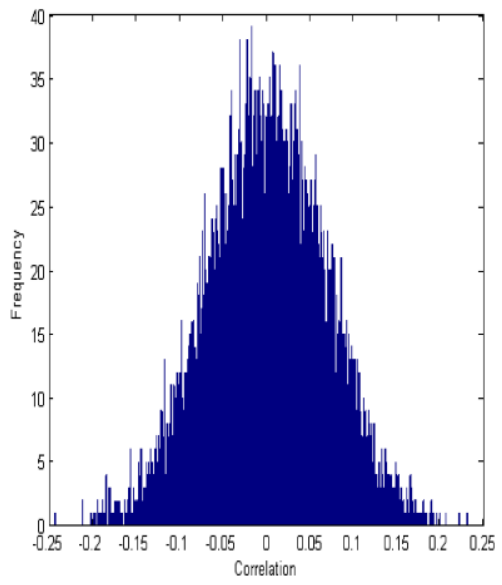

(c)

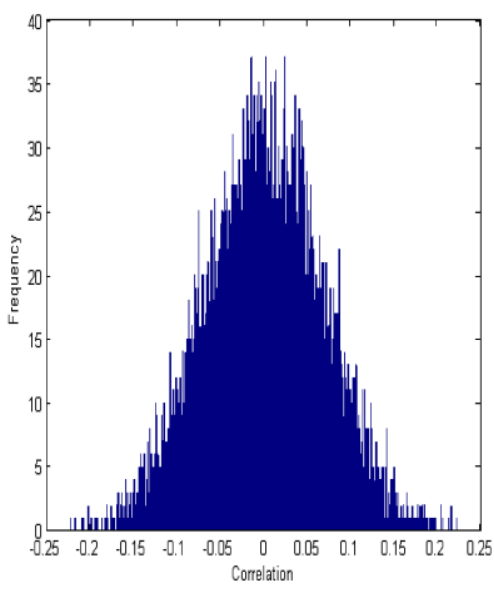

Figure 3 Correlations permutation distribution reconstruction of the resampling test for Emanuel convective schemes (a), Grell/Emanuel convection scheme (b) and Kain-Fritsch convection scheme (c).

It is important to mention that there are physical differences in the convection parameterization schemes that lead to the differences observed in the wind intensity. The Kain-Fritsch convection scheme is based on the Convective Available Potential Energy (CAPE) parameter; it is effectively the positive buoyancy of an air parcel and it is an indicator of atmospheric instability (Kain, 2004). The Emanuel convection scheme considers that the mixture in the clouds is a secondary process and inhomogeneous, whose convective flows are based on a model of ascending and descending currents of scales of subclouds. Convection is then initiated when the neutral buoyancy level is greater than the condensation level by lifting at the base of the cloud. Between these two levels, the air rises and one part of the condensed moisture fraction form 
precipitation, while the remaining part forms the cloud. The cloud, in turn, mixes with the ambient air according to a uniform spectrum of mixtures that drives the parcel up or down, thus reaching the level of neutral buoyancy. The entrainment and dewatering rates are calculated through the vertical buoyancy gradients in the cloud (Emanuel, 1991). The Grell convection scheme is based on the rate of destabilization of a single cloud with upward and downward flows and compensation motions that determine the moisture and heating profiles. This scheme includes downward movements of convective-scale and allows capture under the cloud. The vertical heating and wetting profiles are derived from the latent heat release associated with the mass flows in the upstream/downstream currents and vertical compensation movement (Grell, 1993).

Figure 5 presents the wind rose for the height at $70 \mathrm{~m}$, computed with data from the micrometeorological tower, from June to July 2017, while Figure 6 shows the same information but to the simulations (at $1000 \mathrm{hPa}$ ). Northeast winds are predominant during the study period (Figure 5). In June, all simulations estimated the direction with a $180^{\circ}$ deviation from the predominant direction observed in the northeast quadrant. In July 2017, the model simulated better the predominant direction compared to the observations, but with a small displacement towards the north direction. In rocket launching activities, a major limiting factor is the wind intensity in the first few meters that affect and possibly causing drifts during the launching trajectory. 
Revista Brasileira de Geografia Física v.11, n.06 (2018) 2118-2129
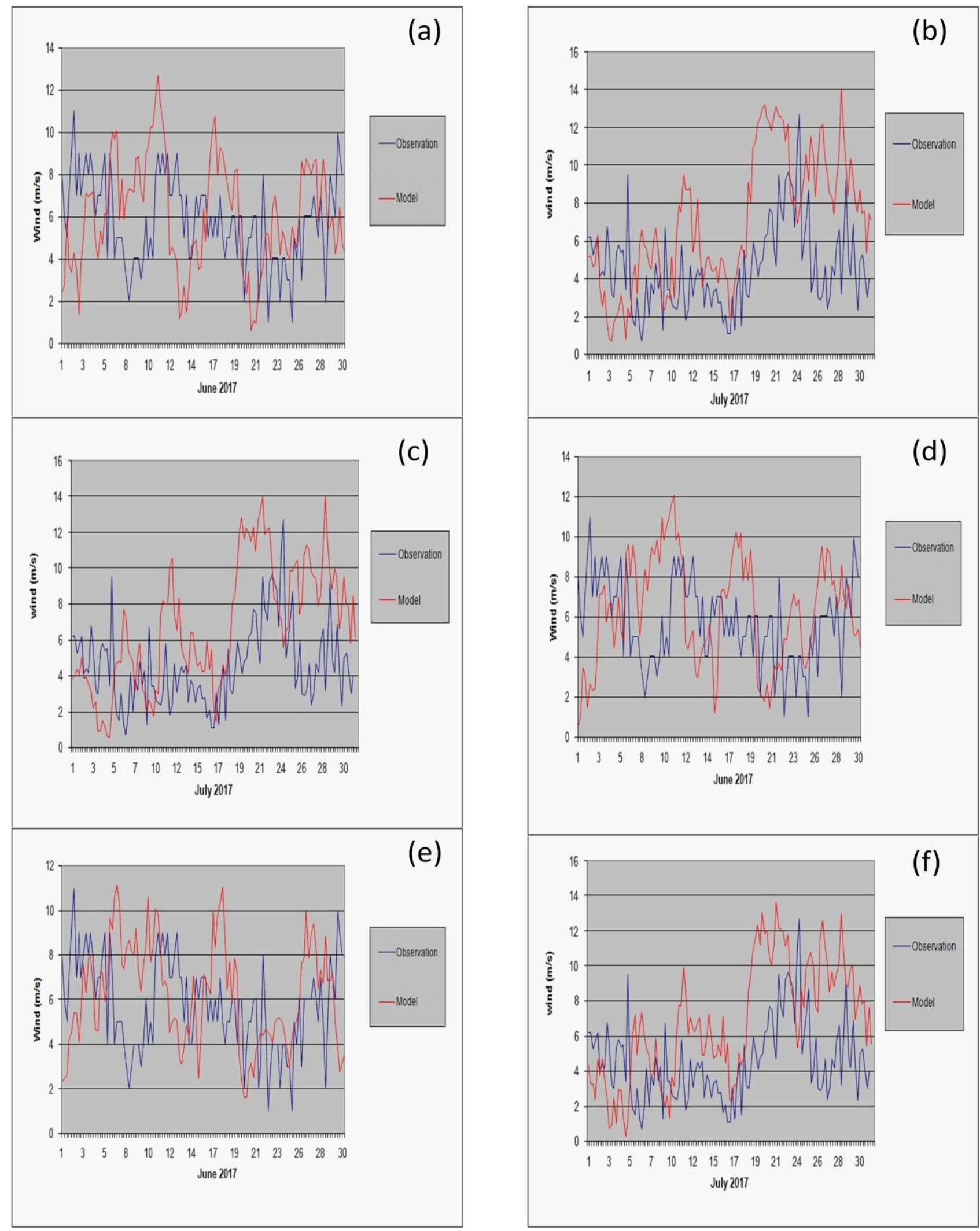

Figure 4. Comparison between the wind intensity from RegCM4.4 using different convection parameterization schemes and the observed data by the micrometeorological tower. Left column indicates June and the right one, July. (a-b) Kain-Fritsch convection scheme; (c-d) Emanuel convection scheme, (e-f) Grell-Emanuel convection scheme. 

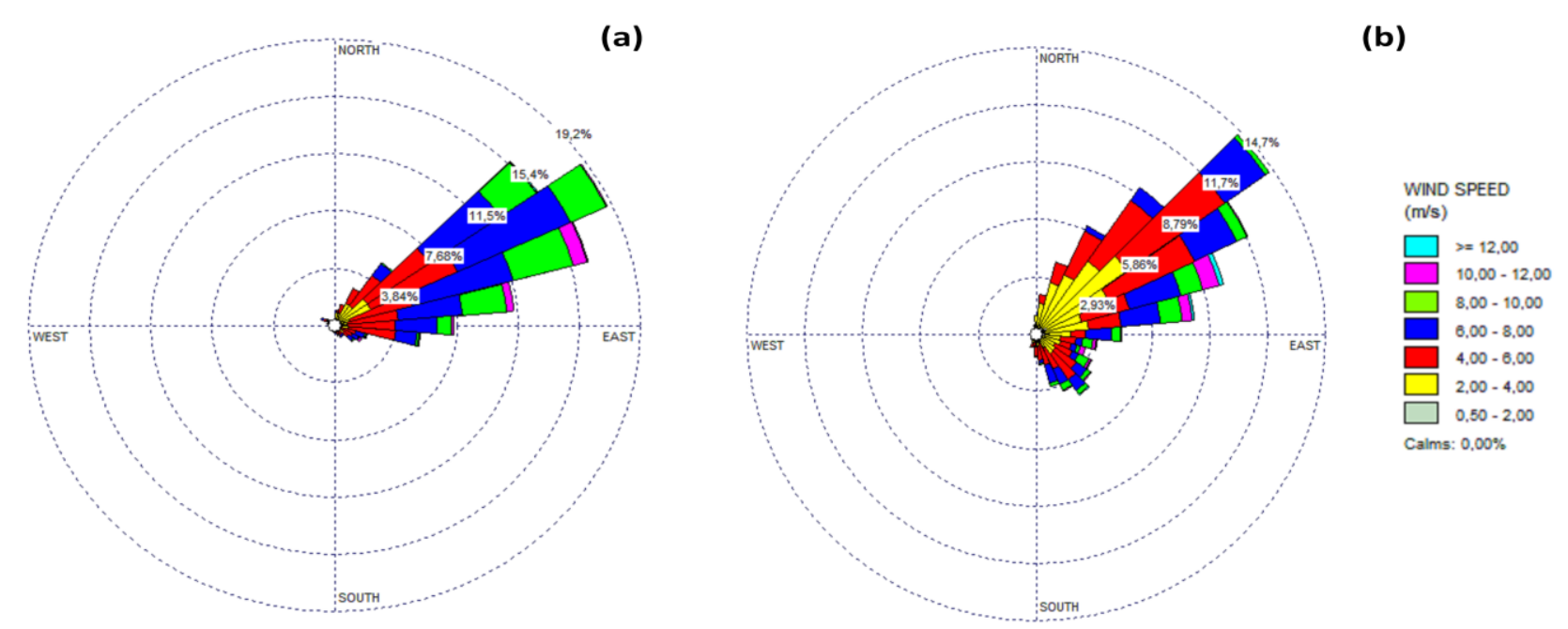

Figure 5 Winds at the level of 70 meters measured by the micro-meteorological tower for June (a) and July (b) 2017. 
Revista Brasileira de Geografia Física v.11, n.06 (2018) 2118-2129
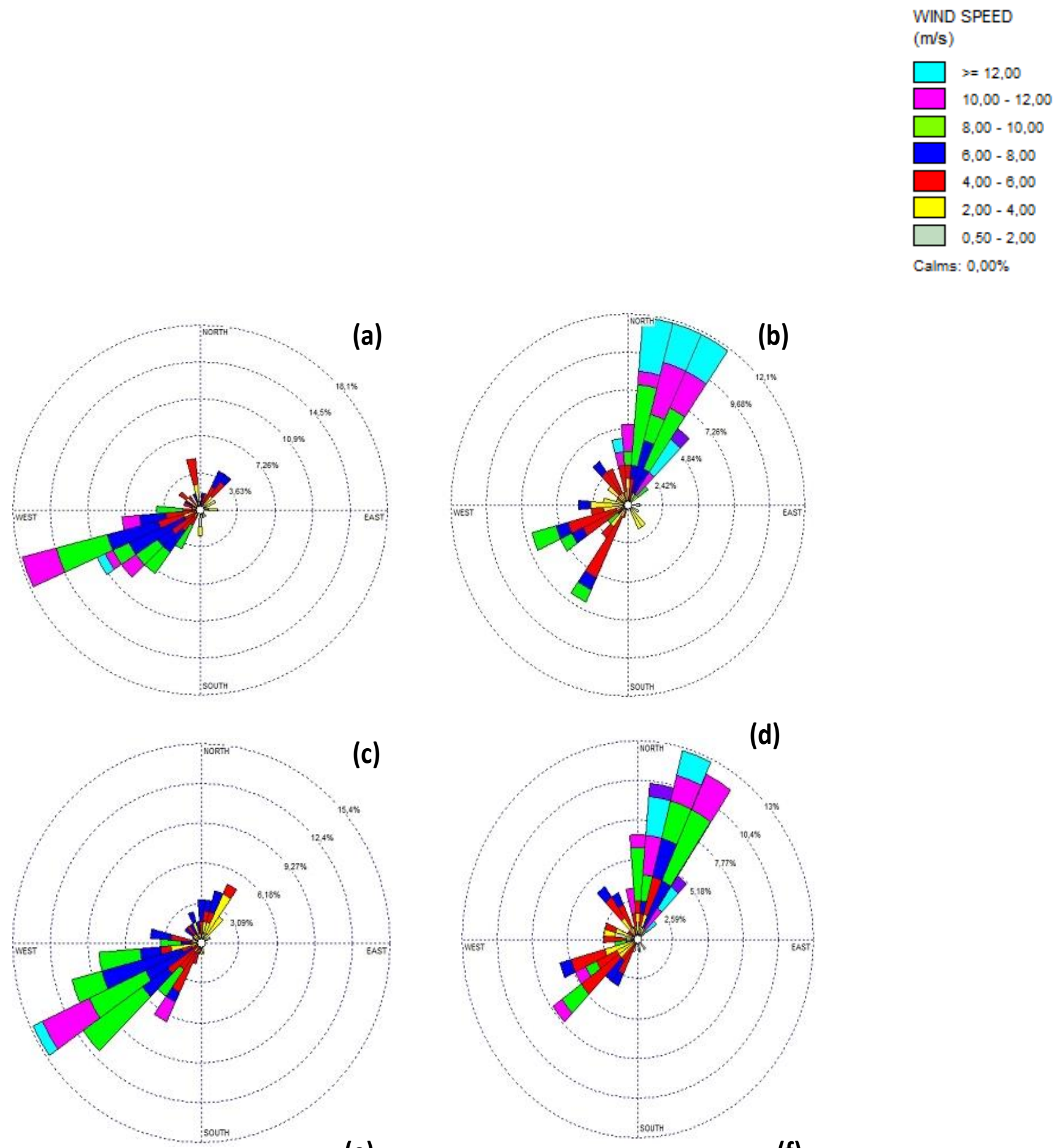

(e)

(f) 
Figure 6. Winds at the level of $1000 \mathrm{hPa}$ simulated for the RegCM4 for June (left column) and July (right column). The lines indicate the simulations with the different convective parameterization schemes: (a)-(b) Kain-Fritsch convection scheme,(c)-(d) with Emanuel convection scheme and (e)-(f) with Grell/Emanuel convection scheme.

\section{Conclusions}

This study evaluated the performance of three simulations of RegCM4.4, nested in the CFSv2 outputs, in the period of June and July 2017. These simulations employed different cumulus parameterization schemes. At ALC, simulations overestimated the wind intensity in about 1-2 $\mathrm{m} \mathrm{s}^{-1}$ at the level $1000 \mathrm{hPa}$ compared with the observations from the meteorological tower (but we need to remember that the level of the model is higher than the meteorological tower). The three simulations presented a similar behavior in estimating the wind intensity, but in the average of the two months (June and July), the best result was obtained from Grell/Emanuel convection scheme. In terms of variability, the wind intensity of the three simulations showed significant statistical correlation with the observation. In summary, the results showed that the RegCM4.4 can be used as a good estimate of the wind intensity, but the wind direction variable cannot be used because the direction was not represented properly. Operationally in the activities of launching space vehicles, the great limit is the wind intensity near the surface.

\section{Acknowledgements}

The authors thank the support of the Instituto de Aeronáutica e Espaço, NCEP by the CFSv2, ICTP by $\mathrm{RegCM}$ and the second author thanks CNPq by the financial support.

\section{References}

Ardilouze, C., L. Batté, and M. Déqué, 2017: Subseasonal-to-seasonal (S2S) forecasts with CNRM-CM: A case study on the July 2015 west-European heat wave. Adv. Sci. Res., 14, 115- 121, doi: https://doi.org/10.5194/asr-14-115-2017.

Batté, L., Ardilouze, C., Déqué, M., 2018. Forecasting west african heat waves at subseasonal and seasonal time scales. Mon Weather Rev. doi: https://doi.org/10.1175/MWR-D-170211.1

Brunke, M. A., P. Broxton, J. Pelletier, D. Gochis, P. Hazenberg, D. M. Lawrence, L.
R. Leung, G.-Y. Niu, P. A. Troch, and X. Zeng, 2016: Implementing and Evaluating Variable Soil Thickness in the Community Land Model, Version 4.5 (CLM4.5). Journal of Climate, 29, 3441-3461. doi: 10.1175/JCLI-D-15-0307.1

Chen, L. and P. A. Dirmeyer, 2017: Impacts of Land-Use/Land-Cover Change on Afternoon Precipitation over North America. Journal of Climate, 30, 21212140. doi: https://doi.org/10.1175/JCLI-D16-0589.1

Chotamonsak, C., Wiranwetchayan, O., Lapyai, D., and Thanado lmethaphorn, P., 2017. Evaluation of WRF-CFSv2 seasonal climate forecasting model over Thailand: the 2016 realtime seasonal forecasts. In EGU General Assembly Conference Abstracts (Vol. 19, p. 17478).

Collingridge, D. S.. 2013. A primer on Quantitized data Analysis and Permutation Testing. Journal of Mixed Methods Research. 7(1): 79-95. doi:10.1177/1558689812454457

Corrêa, C. S., Camillo, G. L., Couto, V. M., Fisch, G., Correa, F. D. N., and Harter, F., 2017. Climate Forecasts at the Centro de Lançamento de Alcântara Using the Climate Model RegCM4. Journal of Aerospace Technology and Management, 9(1), 18-28. doi: http://dx.doi.org/10.5028/jatm.v9i1.649.

De Jesus Reuter, E.D., Fisch, G., and Correa, C.S.. 2015. The Sensitivity of Wind Forecasts with a Mesoscale Meteorological Model at the Centro de Lançamento de Alcântara. Journal of Aerospace Technology and Management, 7(2):247258. doi: http://dx.doi.org/10.5028/jatm.v7i2.388.

Derrick, B., White, P. And Toher, D.. 2018: Parametric and non-parametric tests for the comparison of two samples which both include paired and unpaired observations. Jounal of Modern Applied Statistical Methods. ISSN 1538 - 9472 [In Press] Available from: http://eprints.uwe.ac.uk/37008

Emanuel, K. A., 1991. A scheme for representing cumulus convection in large-scale models. $\mathbf{J}$ Atmos Sci 48:2313-2329. doi: 10.1175/15200469(1991)048<2313:ASFRCC>2.0.CO;2 
Gao, X. J., Y. Shi, and F. Giorgi, 2016: Comparison of convective parameterizations in RegCM4 experiments with CLM as the land surface model over China. Atmos. Oceanic Sci. Lett., 9, 246254, doi: 10.1080/16742834.2016.1172938

Giorgi, F., Elguindi, N., Cozzini, S., Solmon, F., 2015. Regional Climatic Model RegCM User's Guide Version 4.4.

Gonçalves, J. S., 2015. Avaliação da previsão numérica sazonal de precipitação para o Rio Grande do Sul. Dissertação do Curso de Mestrado do programa de Pós-graduação em Meteorologia. Universidade Federal de Santa Maria (UFSM, RS). [Available online at http://repositorio.ufsm.br/bitstream/handle/1/1 0281]. (in portuguese).

Grell, G., 1993. Prognostic evaluation of assumptions used by cumulus parameterizations. Mon. Wea. Rev.. 121, 764$787 . \quad$ (doi: 10.1175/15200493(1993)121<0764:PEOAUB>2.0.CO;2)

Kain, J. S., and Fritsch, J. M., 1990. A onedimensional entraining/detraining plume model and its application in convective parameterization. Journal of the Atmospheric Sciences 47, 2784-2802.

Kain, J. S., 2004. The Kain-Fritsch convective parameterization: an update. Journal of Applied Meteorology 43, 170-181.

Konietschke, F. and Pauly, M.. 2014: Bootstrapping and permuting paired $t$-test type statistics. Stat. Comput. 24: 283. doi: https://doi.org/10.1007/s11222-012-9370

Koopman, J., Howe, M., Hollenbeck, J. R., and Sin, H.-P., 2015. Small sample mediation testing: Misplaced confidence in bootstrapped confidence intervals. Journal of Applied Psychology, 100(1), 194-202. http://dx.doi.org/10.1037/a0036635

McCreight, J. L., Gochis, D. J., RafieeiNasab, A., Yu, W., Mahoney, K., and Alcott, T., 2016. ENSEMBLE STREAMFLOW FORECASTING ACTIVITIES WITH WRFHYDRO. In 2016 HEPEX Workshop- (p. 26).

Oleson, K., and Coauthors, 2013: Technical description of version 4.5 of the Community Land Model (CLM). NCAR Technical Note NCAR/TN-503+STR, $420 \quad$ pp, doi:10.5065/D6RR1W7M.

Pauly, M., Umlauft, M. \& Ünlü, A.. 2018: Resampling-Based Inference Methods for Comparing Two Coefficients Alpha. Psychometrika 83: 203. doi: https://doi.org/10.1007/s11336-017-9601-x
Pushp Raj Tiwari, Sarat Chandra Kar, Uma Charan Mohanty, Sagnik Dey, Palash Sinha, P.V.S. Raju, M.S. Shekhar, 2015. The role of land surface schemes in the regional climate model (RegCM) for seasonal scale simulations over Western Himalaya Atmósfera, Volume 28, Issue 2, pp. 129-142. doi: 10.1016/s01876236(15)30005-9 
Reboita, M.S., Dias, C.G., Dutra, L.M.M., da Rocha, R.P., Llopart, M., 2018, Previsão Climática Sazonal para o Brasil Obtida Através de Modelos Climáticos Globais e Regional. Revista Brasileira de Meteorologia, [online] 33(2):001-018. Available:doi:http://dx.doi.org/10.1590/01 02-7786332001. Access: 22 jun. 2018

Saha, S., Moorthi, S., Wu, X., Wang, J., Nadiga, S., Tripp, P., ... and Ek, M., 2014. The NCEP climate forecast system version 2. Journal of Climate, 27(6), 2185-2208.

Siedlecki, S. A., Kaplan, I. C., Hermann, A. J., Nguyen, T. T., Bond, N. A., Newton, J. A., ... and Feely, R. A., 2016. Experiments with Seasonal Forecasts of ocean conditions for the Northern region of the California Current upwelling system. Scientific Reports, 6, 27203. doi:10.1038/srep27203

Swenson, S. C. and Lawrence, D. M. 2014: Assessing a dry surface layer based soil resistance parameterization for the Community Land Model using GRACE and FLUXNETMTE data, J. Geophys. Res.-Atmos., 119, 299312, doi:10.1002/2014JD022314.

Weber, N. J., and Mass, C. F., 2017. Evaluating CFSv2 Subseasonal Forecast Skill with an Emphasis on Tropical Convection. Monthly Weather Review, 145(9), 3795-3815.

Zhang, Q., Filippi, S., Gretton, A. and Sejdinovic, D., 2017. Large-scale kernel methods for independence testing. Statist. Comput., 27, 118. doi: 10.1007/s11222-016-9721-7

Zou, L. W., T. J. Zhou, and D. D. Peng, 2016: Dynamical downscaling of historical climate over CORDEX East Asia domain: A comparison of regional oceanatmosphere coupled model to stand-alone RCM simulations. J. Geophys. Res., 121, 1442-1458, doi: 10.1002/2015JD023912. 